\title{
Understanding Citrus Greening Disease and Its Possible Management Strategies in Nepal
}

\author{
Sameer Pokhrel ${ }^{1}$, Swikriti Pandey ${ }^{2}$, Ashish Ghimire ${ }^{3}$, Savyata Kandel ${ }^{4}$ \\ ${ }^{1}$ University of Florida, Department of Horticultural sciences, USA \\ ${ }^{2}$ University of Georgia, Department of Entomology, USA \\ ${ }^{3}$ Agriculture and Forestry University, Department of Plant Pathology, Nepal \\ ${ }^{4}$ Agriculture and Forestry University, Department of Genetics and Plant breeding, Nepal,
}

\section{Article Information}

Received: 13 November 2021

Revised version received: 25 December 2021

Accepted: 27 December 2021

Published: 29 December 2021

\section{Cite this article as:}

S. Pokhrel et al. (2021) Int. J. Appl. Sci. Biotechnol. Vol 9(4): 227-238. DOI: 10.3126/ijasbt.v9i4.40805

*Corresponding author

Sameer Pokhrel,

University of Florida, Department of Horticultural sciences, USA

Email: pokhrelsameer60@gmail.com

Peer reviewed under authority of IJASBT

(C) 2021 International Journal of Applied Sciences and Biotechnology

\section{OPEN ACCESS}

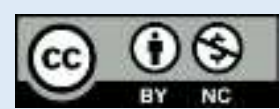

This is an open access article $\&$ it is licensed under a Creative Commons Attribution Non-Commercial 4.0 International

(https://creativecommons.org/licenses/by-nc/4.0/)

\begin{abstract}
Huanglongbing (HLB), also known as citrus greening, is a devastating disease of citrus that has decimated several citrus orchards throughout the world. The disease is associated with three species of unculturable and phloem-limited bacteria, Candidatus Liberibacter asiaticus, Candidatus Liberibacter africanus and Candidatus Liberibacter americanus. The most common species of the bacteria found in Nepal is Candidatus Liberibacter asiaticus which is transmitted by an insect vector, Asian citrus psyllid (Diaphorina citri). This disease has been detected in several economically important citrus production areas of Nepal, which resulted in heavy yield loss. No cure for the disease has been discovered yet and it is essential to practice proper management strategies to maintain citrus health and sustain citrus production under HLB pressure. Several disease-management approaches such as pathogen free nursery establishment, use of disease tolerant rootstock cultivars, proper irrigation and nutrient supply, removal of HLB affected trees and control of psyllid with frequent insecticide application are widely practiced throughout the world. This review article highlights the characteristics of citrus greening disease and its insect vector and gives insights about their management techniques. Several technologically advanced options available to minimize the HLB infection might not be feasible currently in Nepal due to economic and topographic constraints. This article also aims to bring into focus the cost-effective methods that growers in Nepal can practice to mitigate the impact of HLB disease in their citrus orchards.
\end{abstract}

Keywords: citrus production; HLB in Nepal; citrus greening management

\section{Introduction}

Nepal produced 273,000 tonnes of citrus in 2019 and ranked $43^{\text {rd }}$ in global citrus production (Fig. 1). About 177,000 tons of Tangerines, Mandarins, Clementines and Satsumas, and 44,000 tons of oranges were produced in the same year (Fig. 2) (Source: www.fao.org).
The citrus production areas in the world are under the threat of Huanglongbing (HLB) or citrus greening disease (Bove, 2006; McCollum and Baldwin, 2017). The disease has reached most of the commercial citrus production regions and reported in about 50 countries worldwide (CABI, 2020). The detrimental effect of citrus greening has been observed in various countries in the world. 


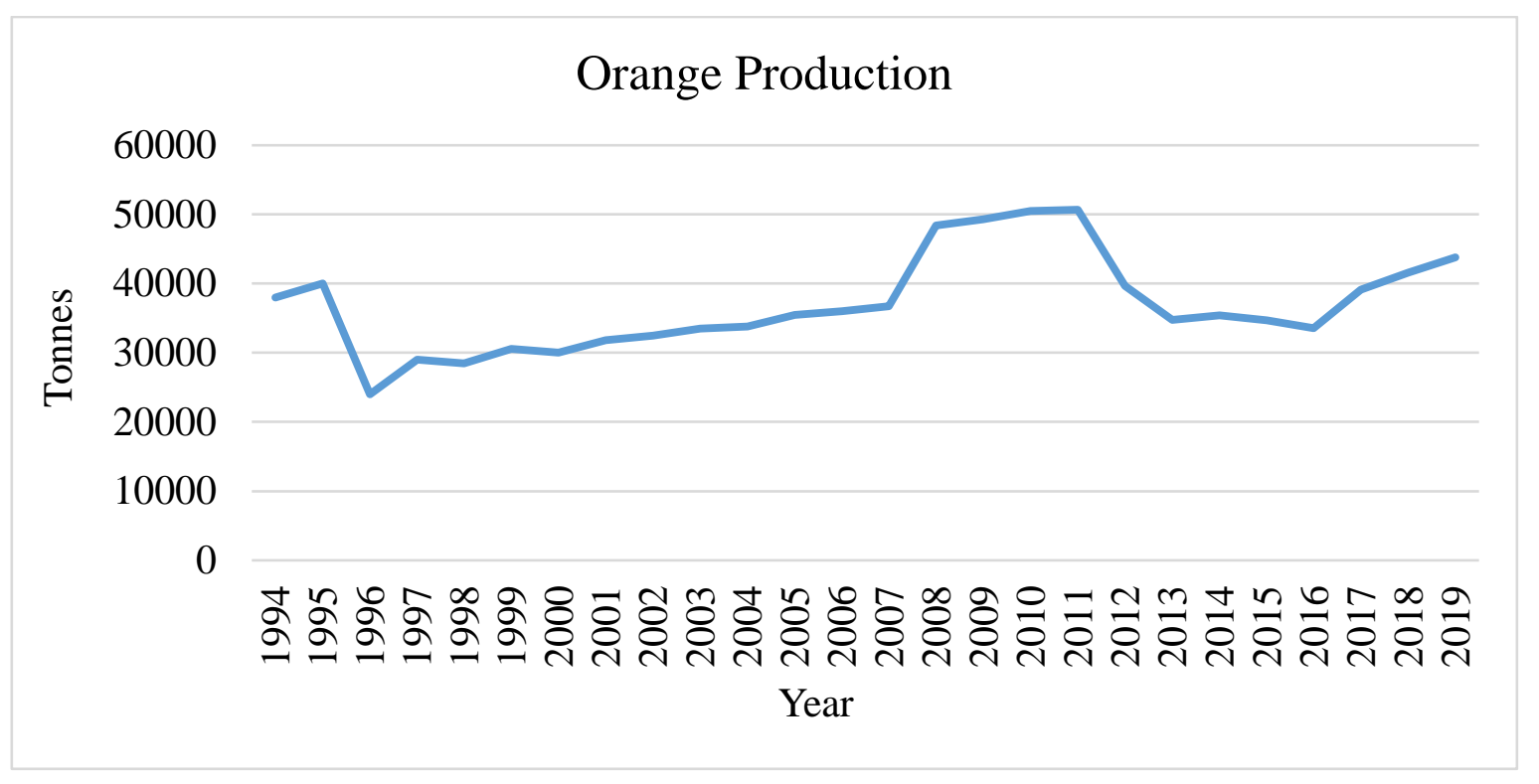

Fig 1: Orange production trend in Nepal (www.fao.org)

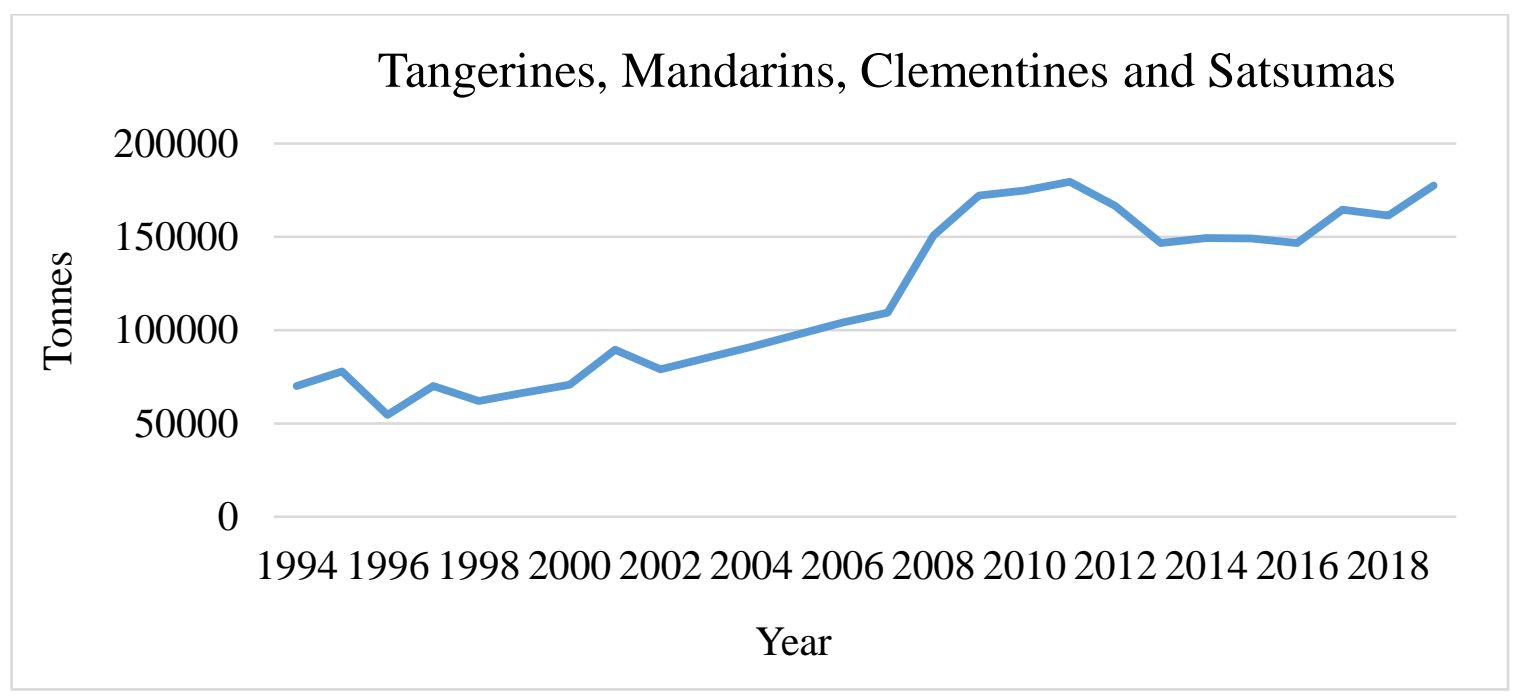

Fig. 2: Tangerines, Mandarins, Clementines and Satsumas production trend in Nepal (www.fao.org)

Citrus greening is associated with three species of gramnegative, unculturable, and phloem-restricted bacteria: Candidatus Liberibacter asiaticus, Candidatus Liberibacter africanus, and Candidatus Liberibacter americanus. Candidatus Liberibacter asiaticus is the most common species distributed all over Asia including Nepal (Paudyal, 2015). The disease is transmitted by an insect vector, Asian Citrus Psyllid (Diaphorina citri).

\section{Symptoms of HLB Disease}

\section{Blotchy Mottle and Yellow Shoots}

Blotchy mottling is one of the characteristic symptoms of HLB. The mottling of leaves in HLB infected plants differs from other nutrient deficiency symptoms in that the yellowing is not symmetric across the leaf midrib (see Fig. 3A) and usually crosses leaf veins (Bove, 2006; Halbert and Manjunath, 2004). Besides blotchy mottling, infected leaves may also become thicker, leathery, upright along with the development of interveinal chlorosis. Midribs and lateral veins may sometimes become enlarged, swollen, and corky. In advanced stages of infection, it can eventually be accompanied by zinc deficiency making the leaves have an upright growth with a close angle with the shoot (Bove, 2006). Yellowing can occur in one or several shoots which with time, grows into a larger yellow branch later spreading throughout the canopy (Weinert et al., 2004). Off-season bloom and twig dieback are additional symptoms exhibited on the shoots (Halbert and Manjunath, 2004).

\section{Symptoms on Fruit and Juice Quality}

Affected fruits look small, asymmetrical, lopsided, and with thicker albedo at the peduncular end. The peduncular end turns yellow/orange but the stylar end may remain green and small, brownish/black aborted seeds could also be observed. Premature fruit drop is very common in HLB affected fruits (McCollum and Baldwin, 2017). The offflavor of juice from HLB affected fruit is a result of lower 
sugars, higher bitter limonoids, flavonoids, and terpenoid volatiles (Baldwin et al., 2018). The symptomatic fruit also shows lower juice content, lower Total Soluble Solids (TSS) and TSS/Titratable Acidity (Bassanezi et al., 2009; Montesino and Stuchi, 2009).

\section{Symptoms on Roots}

Candidatus Liberibacter asiaticus is found to severely affect the fibrous root system. This bacterium first colonizes in roots before showing symptoms infecting leaves (Johnson et al., 2014). The damage on the root system, especially the loss of fibrous roots can be severe before any symptoms are seen in the canopy. The roots could also be starved led by the accumulation of food resources in the form of stored carbohydrate in the aerial parts inhibiting nutrient partitioning (Dala-Paula et al., 2019; Zheng et al., 2018). The symptoms of HLB are considered to be more apparent during cooler seasons compared to warmer seasons (DalaPaula et al., 2019, McCollum and Baldwin, 2017).

\section{Asian Citrus Psyllid}

Asian citrus psyllid (ACP), Diaphorina citri Kuwayama (Hemiptera: Psyllidae) is a small plant feeding insect with the size of an adult ranging from 2.7-3.3mm long and identified by distinctive mottled brown wings and abdomen with three color ranges: gray/brown, blue/green and orange/yellow (Fig.4). The insect has five instars with docile early instars and mobile older nymphs and adults. The eggs are oval with light yellow color when freshly deposited and distinctive red eye spots when mature (Hall et al., 2013) Citrus psyllid (Diaphorina citri) damages the plant by sucking the sap from the foliage and excreting sugary substance that covers the leaf with honeydew which then gets covered by sooty mold. As there is no remedial therapy available for the HLB disease, it is important to reduce the transmission of the disease by controlling its vector (Yan et al., 2015).

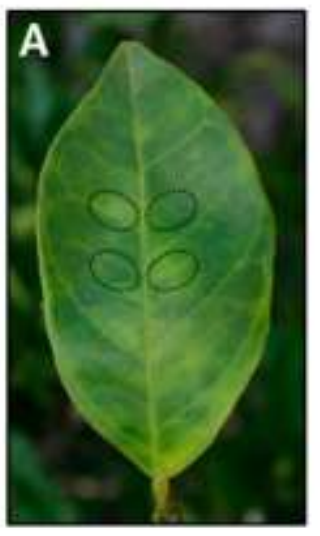

E

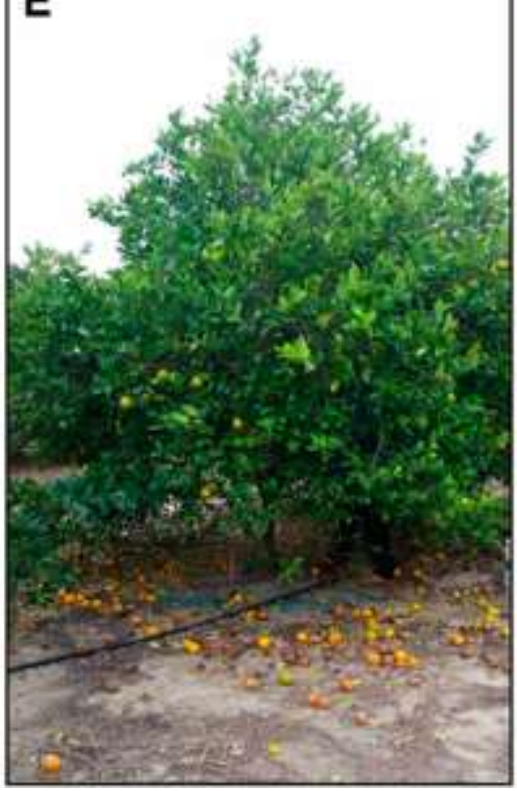

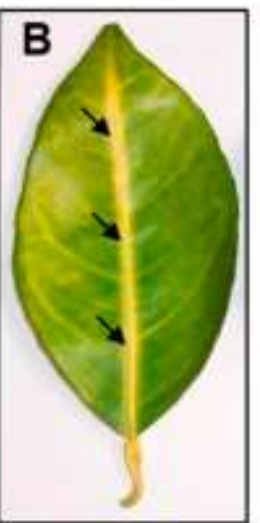
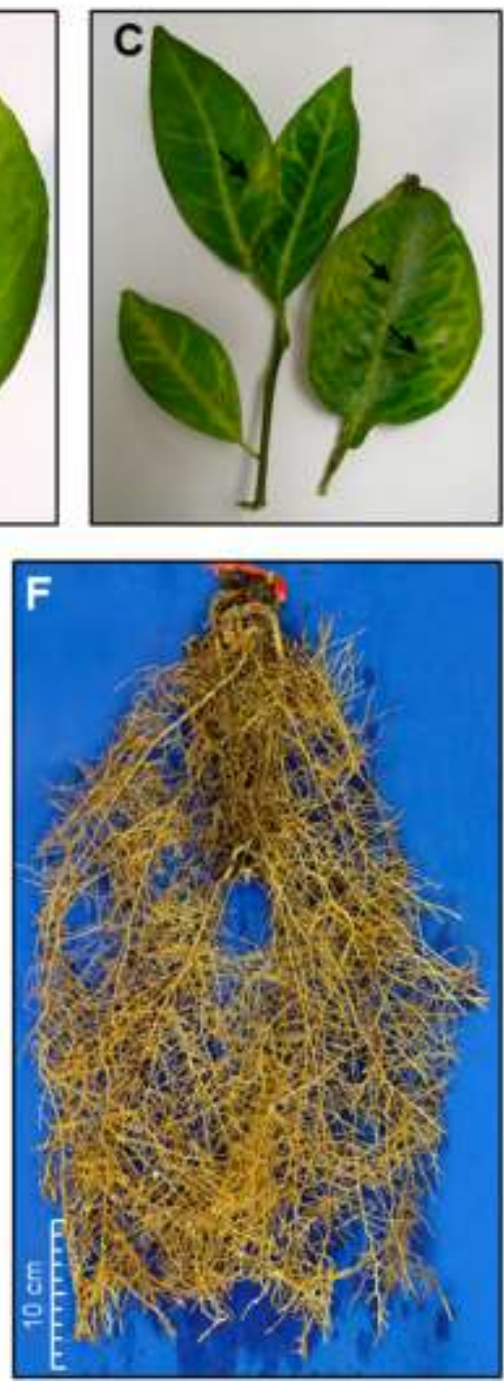
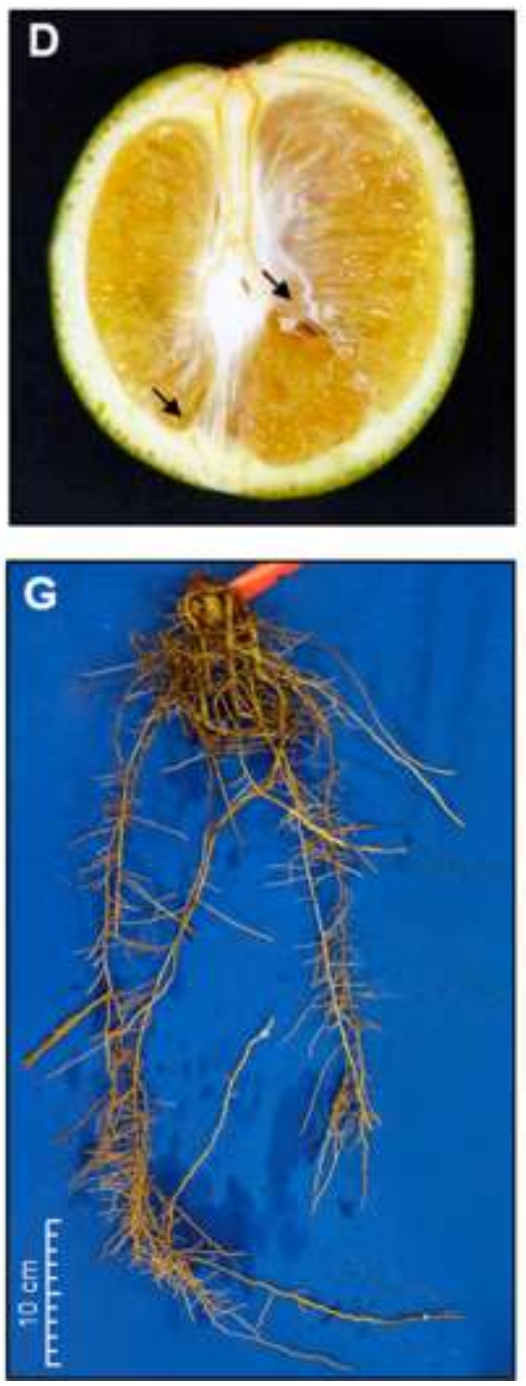

Fig. 3: Symptoms related to HLB disease: (A) Asymmetrical blotchy mottle in leaves (B) Yellow coloration in leaf vein (C) Leathery leaves and corky veins (D) Lopsided and asymmetrical fruits with aborted seeds (E) Severe pre-harvest fruit drop (F) Healthy roots and $(\mathrm{G})$ severe fibrous root loss due to HLB disease. (Source: Nehela and Killiny,2020) 


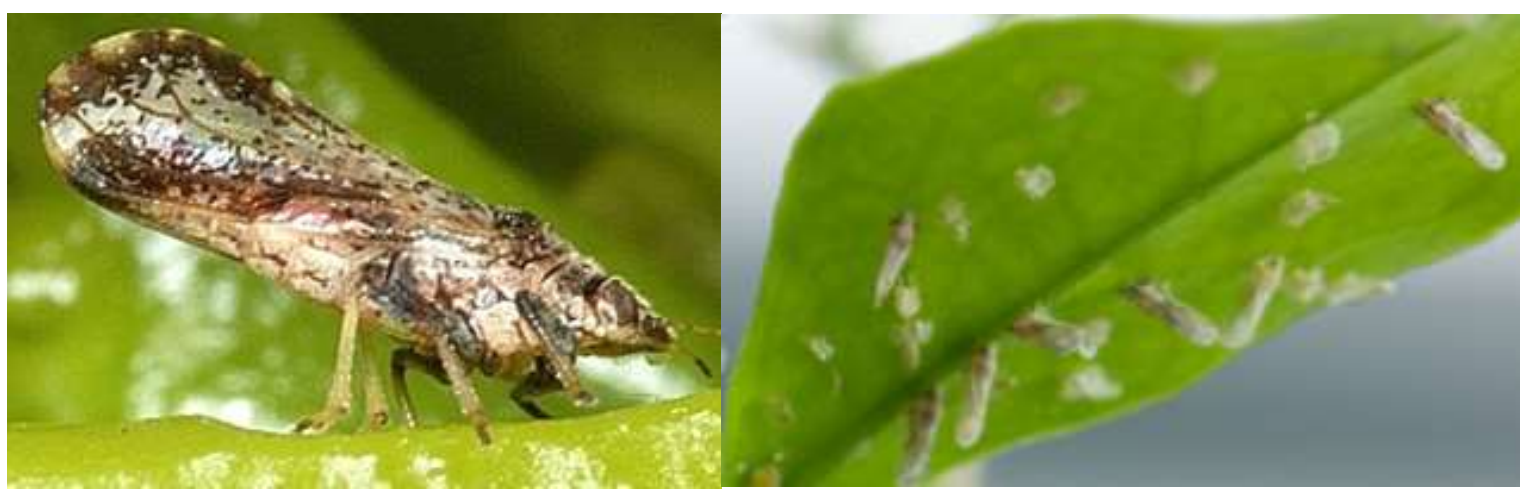

Fig. 4: Images of Asian Citrus Psyllid. Source: www.aphis.usda.gov

\section{HLB and Economic Loss}

HLB spreads rapidly throughout the tree canopy and in the orchard, reducing the economic life of affected trees (Bove, 2014). As no cure for the disease has been found, growers need to rely on various management techniques in order to maintain the tree's health and longevity. Those management strategies often have very high costs associated with them (Li et al., 2020).

Since the advent of HLB disease in Florida in 2005, the citrus production in the USA has dropped from 16 million tons in 2003-04 to 8 million tons in 2019-2020 (www.nass.usda.gov). In the same time period, the reduction in citrus production in Florida was from about 13 million tons to 3 million tons. It has been estimated that the cultural cost to manage HLB in citrus orchards in Florida has been increased by $67 \%$ compared to pre-HLB period (Singerman, 2019).

HLB damaged millions of hectares of citrus orchards in China (Li et al., 2020), which is believed to be one the places of origin of the disease. Citrus production in Guangdong, Guangxi and Fujian provinces has been severely affected and a recent HLB outbreak in 2013 in Ganzhou, Jiangxi province resulted in the destruction of about 50 million trees. In previous years, HLB had decreased the productivity of citrus up to $80 \%$ in different areas of India (Singh, 1977). It was suspected that more than 40-70\% trees were infected in Thailand and Nepal in past years (Regmi, 1982).

\section{HLB History}

There is no definite evidence of the origin of HLB disease. It was observed as early as in 18th century in India, which was first thought to be associated with Citrus tristeza virus but later suggested to be citrus greening (da Graca, 2008). The HLB disease has been known to be existing in China for more than a century (Zhao, 1981). The clear symptoms of disease were observed in 1938 (Chen,1943) and in 1927 the insect vector Diaphorina citri was first described (Husain and Nath,1927). In South Africa, symptoms for the disease were observed in 1937 (van der Merwe and Anderson, 1937). The disease was mostly detected and was rapidly spreading during the 19 th century. It has reached over 50 citrus producing countries of Africa, Asia, Europe, North America and South America ( https://www.cabi.org/isc/datasheet/16567).

China and India, the two neighboring countries of Nepal were among the first countries to report the symptoms of HLB disease in citrus (da Graça, 2008; Bove, 2006). HLB is believed to be transmitted in Nepal while importing the rootstocks from Uttar Pradesh, India. The disease symptoms of tree decline were reported for the first time in Nepal in Pokhara valley in 1968 (Thrower, 1968). Catling (1968) visited that area and considered that the citrus decline was associated with HLB disease. It was later confirmed that 54\% among 132 trees sampled from the location (Pokhara to Ranigaun) were infected by citrus greening disease (Knorr et al., 1970). The same study also suggested the HLB incidence rate of $53 \%$ in west Nepal, $43 \%$ in Kathmandu valley and 59\% in east Nepal. By 1982, $55 \%$ of trees in Pokhara valley and $100 \%$ of trees in Horticulture research station were found symptomatic of citrus greening disease (Regmi, 1982). Recently, the disease has been detected on several important citrus production regions of Nepal as evident by the presence of citrus psyllid, visual disease symptoms and other confirmatory tests (Manandhar et al., 2004; Regmi et al., 2010; Regmi and Yadav, 2007).

\section{Host Range and Ecology for Disease Progression}

Although all citrus species could be affected by HLB (Bové, 2006), those species had shown variable responses. Sweet orange, mandarin and tangelo trees were severely affected while other species had displayed more or less pronounced symptoms. Even though Mexican lime (Citrus aurantifolia) is a preferred host of the vector Diaphorina citri (Roastcher, 1996), it was less susceptible than sweet orange and mandarin. However, the mandarin hybrid 'Sugar Bell' was found tolerant to HLB disease (Killiny et al., 2017). Besides those cultivated citrus species, other species of Rutaceae family such as cape chestnut (Calodendrum capense), Orange Jasmine ( Murraya paniculata), and Kumquats (Fortunella) are also the hosts of Huanglongbing disease (www.cabi.org/isc/). 
HLB transmission is feasible between 16 to $33^{\circ} \mathrm{C}$ with peak transmission at around $25^{\circ} \mathrm{C}$ (Taylor et al., 2019). The disease progression is highly favored near the equator's large citrus-producing regions such as Brazil and SouthEast Asia. The Asian Citrus psyllid is tolerant to heat and can withstand $30-35{ }^{\circ} \mathrm{C}$ but the optimum range for its development is $25-28^{\circ} \mathrm{C}$ (da Graca and Korsten, 2004).

The presence of cultivated and wild host plants for HLB disease progression and the favorable climate for HLB transmission and psyllid development in citrus production areas of Nepal renders Nepalese citrus orchards vulnerable to citrus greening disease.

\section{HLB Detection}

Besides the visual symptoms as mentioned previously in this article, there are several other methods to detect the HLB disease in Citrus sp. One of the simple and faster diagnostic methods is by using the Iodine test. (Taba et al., 2006). Citrus greening leads to starch accumulation in the leaves (Etxeberria et al., 2007). The starch reacts with iodine to give a dark gray to black stain, which can be a convenient way to identify HLB disease. The correct selection of the infected leaves and the concentration and quality of the iodine solution used in the test determines the accuracy of the scratch test (Adhikari et al., 2012).

HLB symptoms are often mistaken for leaf nutrient deficiencies. Pen test is a simple tool that helps to distinguish the asymmetrical pattern of chlorosis due to HLB as compared to the symmetrical chlorosis because of mineral deficiencies (Vashisth and Kadyampakeni, 2020). In this test, a circle needs to be drawn on each side of midvein of a leaf. If the same pattern of Chlorosis is observed within two circles, it indicates the nutrient deficiency symptom while different pattern indicates the possibility of HLB disease.

A real time PCR (RT-PCR) has been widely used for the detection of the citrus greening bacteria. It is based on the use of appropriate primers and probes that amplify DNA sequences of Liberibacter associated with HLB (Li et al., 2006). HLB can also be detected using spectroscopy technique. Canopy reflectance spectra can be measured on both infected and healthy trees using a spectroradiometer. using three common classification algorithms to distinguish the infected trees from the healthy trees. By using multiple spectral measurements from the canopy of a single tree, the classification accuracy can be increased (Mishra et al., 2012).

\section{HLB Management Strategies}

HLB-affected trees, if not removed and managed in time, serve as the inoculum source. A minimum of 15 minutes of feeding by the psyllid is sufficient to transmit the causal agent of citrus greening to the healthy plants (Hall et al., 2007). Therefore, early scouting when the number of infected trees is low and more frequent scouting if the disease has been present on the field or nearby will help in managing HLB disease. It is important to use the propagation material from disease free nursery to reduce the damage of HLB infection during early growth stage. Once the majority of trees in the orchards are infected by the citrus greening disease, it is hard to control the disease. Following options are commonly practiced in order to maintain tree health and sustain the tree yield despite the presence of the disease in the field.

\section{Use of HLB-Tolerant Citrus Rootstocks}

Citrus rootstocks have played an important role in the management of diseases such as gummosis, Phytophthora root rot, and citrus tristeza virus during the $19^{\text {th }}$ and $20^{\text {th }}$ century (Bowman and Joubert, 2020). The necessity of grafting desirable citrus varieties with the disease free and high-quality rootstocks was realized several years ago in Nepal (Regmi et al., 2010).

There are several rootstocks that are tolerant to HLB disease (Albrecht and Bowman, 2011; Ramadugu et al., 2016; Kunwar et al., 2020). Grafting the desired scion on the HLB tolerant rootstocks can be an effective HLB management strategy without addition of extra cost. Rootstock cultivars such as 'US-897' ('Cleopatra' mandarin [Citrus reticulata] $\times$ 'Flying Dragon' trifoliate orange [Poncirus trifoliata] (Albrecht and Bowman, 2011), 'US-942' (C. reticulata 'Sunki' $\times$ Poncirus trifoliata 'Flying Dragon') (Bowman et al., 2016), and Carrizo citrange (C. sinensis $\times$ Poncirus trifoliata) (Albrecht and Bowman, 2012) were found tolerant to HLB disease. Similarly, the rootstocks 'US-802' ('Siamese' pummelo [Citrus maxima] × 'Gotha Road' trifoliate orange [Poncirus trifoliata]), and 'US-812' ('Sunki' mandarin $\times$ 'Benecke' trifoliate orange) were found moderately tolerant to citrus greening (Albrecht and Bowman, 2012).

The altitude for citrus production in Nepal ranges from 450 masl to 1300 masl (Manandhar et al., 2004). Mandarin orange is an indigenous fruit of Nepal (Bonvia, 1989) and several desirable varieties are locally available (Gautam et al., 2004). Several trifoliate and other rootstocks are also already in use in the country (Lama, 2004). Conducting research on HLB tolerant rootstocks and scion cultivars in various ecological zones of the nation facilitates the exploration for the best performing rootstocks and scion partners under HLB pressure.

Citrus are commonly propagated by seeds as nucellar polyembryony can produce true-to-type plants from seeds (Koltunow et al., 1995). Trees can take several years for seed production and some of the rootstocks might not exhibit nucellar polyembryony. In such cases, they can be propagated alternatively by cuttings or tissue culture (Pokhrel et al., 2020). This is important in Nepal as the country has diversity in citrus genotypes (Budathoki et al., 
2004), but there is limited commercialization of many citrus varieties.

\section{Irrigation, Nutrition Management and Hormones}

In comparison to healthy trees, HLB-affected trees bear weaker root systems and also have been reported to have lower concentration of nutrients like Potassium, Calcium, Magnesium, Copper, Iron, Zinc, and Manganese (Vashisth, 2016). Frequent application of small doses of fertilizers (in leaves or roots) enabling regular supply of nutrients are more effective in reducing potential nutrient leaching. Fertigation and controlled-release fertilizers are also effective nutrient delivery methods (Phuyal et al., 2020; Morgan et al., 2016).

In a study by Uthman et al. (2020), it was suggested that for up to $224 \mathrm{~kg} \mathrm{~N} \mathrm{ha}^{-1}$ supply, the leaf $\mathrm{N}$ concentration, canopy volume and yield of HLB-affected trees increased whereas beyond that level no additional advantage was obtained. Atta et al. (2021) also found out that split ground application of $224 \mathrm{kgha}^{-1}$ of $\mathrm{N}$ and both foliar applied coupled with ground-applied $\mathrm{Mn}$ and $\mathrm{Zn}$ each at $9 \mathrm{kgha}^{-1}$ sustainably supplied these nutrients within optimum ranges and further improved vegetative growth of HLB-affected trees. Foliar sprays are widely used but more expensive than soil-applied fertilizers and are more affected by regular rainfall, high temperatures, and heavy wind (Phuyal et al., 2020)

Brassinosteroids, a relatively new class of phytohormones has shown good results against HLB through reduction in symptoms following early bloom, reduced fruit drop and increased yield (Alferez et al., 2019). Foliar application of Epibrassinolide, a type of Brassinosteroid, resulted in no reemergence of symptoms in new shoots whereas the old leaves retained the symptoms. An application of another plant hormone 'Strigolactone' on HLB-affected trees was found to reverse certain physiological processes responsible for tree decline by restoring tree growth and mobilizing carbohydrate. Strigolactone application on HLB affected tree was found to increase the number of flowers bearing branches, active flowers, fruit setting and additional summer flushes (Zheng et al., 2018). Studies have suggested that frequent irrigations with smaller quantities of water benefit HLB-affected trees in terms of improvement in tree canopy density, leaf area, and reduction in leaf fall. Higher content of bicarbonates in irrigation water escalates the problem of higher fibrous root loss due to HLB (Vashisth, 2016).

\section{Other Strategies}

The application of aqueous extract from Quercus hemisphaerica has been found to reduce the bacterial titer and enhance the overall tree physiology of HLB affected trees. The trees treated with oak extract had better stomatal conductance, chlorophyll content and nitrogen uptake (Pitino et al., 2020). Several oak species such as Quercus glauca (Pokhara); Quercus semecarpifolia: Lumle, Phulchowki (Kathmandu); Quercus incana: Hattiban (Kathmandu) are found in Nepal (Adhikari, 2014). This suggests a possibility of evaluating the effect of oak extracts for the management of citrus greening disease in the country.

HLB management strategies also include foliar spray, root drench and trunk injection of antibiotics (Puttamuk et al., 2014; Zhang et al., 2011). Peptide conjugated morpholinos (PPMOs) have been applied to prevent bacterial growth (Wesolowski et al., 2013; Hegarty and Stewart, 2018). The continuous exposure of infected citrus seedlings to 40 to 42 ${ }^{\circ} \mathrm{C}$ heat for at least 48 hours has been reported to be sufficient to reduce pathogen titers (Doud et al., 2017). However, all these methods are often debatable and have limited success. Furthermore, these technologies involve very high cost and currently might not be feasible for Nepalese growers.

\section{Strategies to Manage Citrus Psyllid (Vector Control)}

The psyllid is reported to be spread from eastern to western borders of citrus producing areas of Nepal (Regmi et al., 2010). The vector prefers lower altitude and hot and dry conditions (Hall et. al., 2007).

\section{Chemical Management}

Since the timing of pesticide use is critical for management of citrus psyllids, monitoring of the pest through scouting of the pests and use of yellow sticky traps is necessary to time control action (Halbert and Manjunath, 2004; Hall et al., 2013). Reduced population of ACP can be achieved when the intensive insecticides are applied at peak citrus flushing period (Hall et al., 2013). The use of foliar and systemic insecticides such as imidacloprid, fenpropathrin, chlorpyrifos and dimethoate are considered an effective approach to reduce the citrus psyllid numbers. The approach of using the aqueous solution of either $0.05 \%$ dimethoate or $0.02 \%$ chlorpyrifos or imidacloprid at bud burst stage for the control of citrus psyllid is also followed in India and China (Department of Agriculture, 2011) and are also readily available in the Nepalese markets (Bhusal et al., 2019; Diwakar et al., 2008). It is found that systemic soil applied imidacloprid properties has less impact on natural enemies (Boina et al., 2009) and also provides a longer period of protection than many foliar insecticides (GraftonCardwell et al., 2013) The systemic soil applied imidacloprid were also found to decrease their potential of acquiring and transmitting the HLB pathogen (Boina et al., 2009). Systemic insecticides are most useful in the young trees that flush more regularly and require constant protection. Rotation of pesticides with different mode of actions should be considered to prevent psyllids from developing resistance against the used pesticides (Tiwari et al., 2011). 
Horticultural oils and Insect Growth Regulators (IGRs) are found to be more effective against eggs and nymphs than adults (Grafton-Cardwell et al., 2013). In some studies, essential oil from Artemisia absinthium is also found toxic to the psyllids but its toxicity was reported to be weaker than synthetic insecticides (Rizvi et al., 2018). However, the availability of the essential oils in the Nepalese market might render its use in HLB management (Bhusal et al., 2019).

\section{Biological Control}

Increased use of insecticides for the control of the D. citri may cause negative impact on natural enemies, parasitoids and predators. The alternative to chemical management is the use of biological control. In Asia, the native parasitoids Tamarixia radiata and Diaphorencyrtus aligarhensis are found to attack and control ACP (Hall et al., 2013). In studies conducted by Chien and Chu (1996) in Taiwan and Michaud (2002) in Phillippines, these two parasitoids were found effective in parasitizing ACP nymphs in both laboratory and field conditions. A study by Khan et al. (2016) found that Adalia bipunctata adults and larvae fed on the diet of $D$. citri nymphs. A. bipunctata (Coleoptera: Coccinellidae) is found in the various crop and forest ecosystem in Asia and was also observed in the field crop survey in Pakistan along with other species of coccinellids that might potentially be predatory to D. citri (Khan et al., 2016). In a study conducted by Qureshi and Stansly (2009), the cohorts of $D$. citri that were protected by cages from natural enemies were found to have low mortality compared to the unprotected ones and the significant natural mortality was attributed to lady beetles (Qureshi and Stansly, 2007). The predatory mites Ambylseius swirskii were also found useful in reducing $D$. citri through feeding on its eggs and neonates (Juan-Blasco et al., 2012). Pathogenic fungi like Cladosporium sp., Capnodium citri, Hirsutella citriformis have been used for biocontrol purposes since a long time (Halbert and Manjunath, 2004; Hall et al., 2013).

\section{Physical and Chemical Repellents}

The use of physical repellants like kaolin clay particle film and metallized polyethylene mulch is also an area of research in citrus psyllid management (Croxton and Stansly, 2014; Grafton-Cardwell et al., 2013; Hall et al., 2007). The effectiveness of kaolin clay particles is accounted to the fact that the clay particle film inhibits the grasping, oviposition ability and movement of the psyllid adults. However, kaolin poses the problem of being easily washed away by the rain or being ruptured by growing and expanding shoots (Hall et al., 2007). Therefore, care should be taken while selecting a proper day and time of kaolin application. Use of pest exclusion nets can also exclude the psyllid from citrus trees and can help to produce HLB free trees during young growth stage (Alferez, 2019).

Intercropping of guava (Psidium guajava) with citrus plants was found to decrease psyllid population and increase longevity of citrus trees compared to monocultures in Japan and Australia but the results are not consistent (Hall et al., 2013). Gas chromatography- mass spectrometry (GC-MS) analysis attributed the repellence of psyllids to the plant volatile dimethyl disulfide (DMDs) present in wounded guava leaves (Rouseff et al., 2008; Onagbola et al., 2011). The plant volatiles present in garlic chives (Allium tuberosum) disulfides and trisulfides, volatile oils extracted from non-host plants Mikania micrantha, Lantana camara, Eupatorium catarium, Wedelia chinensis were found to reduce the number of ACP adults (Yijing et al., 2005; Mann et al., 2011).

Studies also suggest the attraction of citrus psyllids to the chemical methyl salicylate which is produced by infested pear trees (Molleman et al., 1997) as well as ACP infested citrus trees (Mann et al., 2012). The presence of host plants of preferred family, Rutaceae, such as Murraya paniculata and Citrus paradisii were found to be determinant in increasing psyllid densities (Tsai and Liu, 2000). The odor from the host plants infected by Candidatus liberibacter were found to be significantly attractive to psyllid oviposition and adult population (Zhao et al., 2013). They were also found to react to olfactory and visual cues like bright yellow and green of the flushing shoots for the detection, location and evaluation of potential hosts (Wenninger et al., 2009). This information can be useful in understanding the management strategies for the control of the psyllid population by getting rid of psyllid host plants (Department of Agriculture, 2011) or developing an attract and kill approach by trap cropping, intercropping or using chemicals (Yan et al., 2015). It is found that extremely low temperatures limit the development and dispersal of D. citri (Wang et al., 2019). In Asia, Diaphorina citri was not found above the elevation of 1300-1500m which could be due to its low frost tolerance and weak flight ability making them unable to sustain long distance flights (Halbert and Manjunath, 2004; Hall et al., 2013). It opens the possibility of establishing citrus nurseries in the high hills of the country to observe whether those nurseries would be free from HLB infection. However, it is also equally essential to consider the physiology of citrus under the chilling temperature of those regions.

\section{Quarantine and Regulation}

The geographical range of Asian citrus psyllid and HLB is ever expanding (Hall et al., 2013) and the intervention for its management is mostly ineffective (Taylor et al., 2019). Citrus production is a great contributor to the economy of the United States and Brazil, but these countries are facing severe decline of citrus due to citrus greening (Olexa and Benn, 2018). The first line of defense for the management of ACP and HLB is restricting the movement of infested plants and quarantining areas where the pests are abundant (Hall et al., 2013). The estimation of maximum flight distance could be a good measure of determining proper 
quarantine strategies for HLB management. In Nepal, 30 $\mathrm{km}$ of separation was found to be sufficient (Halbert and Manjunath, 2004). However, more research is necessary to support the claim. Citrus growing regions all over Nepal are impacted by HLB (Department of Agriculture, 2011). Nepal has developed various strategies and survey protocols to combat the problem of citrus decline. Some of these strategies include detailed survey of citrus greening and virus incidence, survey of alternate hosts, and identification of disease-free citrus growing areas. Government of Nepal has identified lack of internal quarantine as a problem that has been causing the flow of uncertified plant materials in and out of the country. The major problem lies within the small land holding $(<0.5 \mathrm{ha})$ of citrus cultivating growers and small production volume as well as open border with India that makes implementation of management strategies more difficult (Department of Agriculture, 2011).

The same problem is faced by the USA and Brazil, both the countries have been working together through information dissemination and knowledge sharing to understand the pathogen and the disease best possible (Olexa and Benn, 2018). The collaborations of the government agencies with the agriculture universities in the US has helped research on the problem and find potential solutions like the USDA funded projects in University of Florida Institute of Agriculture and Food Sciences. Local grower group (Citrus Health Management Areas) has been formed in Florida that coordinates the rotation of pesticides amongst themselves to ensure pest resistance doesn't pose a problem. The Florida legislature has also passed the Greening Removal or Vector Elimination (GROVE) program that helps growers that wish to remove and replant infected plants by cost sharing. The Federal government of Brazil has also placed policies and rules to citrus growers to inspect and report the citrus groves quarterly. The Agriculture Defense Coordination of Sao Paulo, Brazil is also responsible for enforcing laws for nursery management, providing resources to growers to mitigate the citrus greening problem and also regulating the rootstocks used by the growers. In Brazil, growers have started working together to remove and replant the citrus trees which has been effective in managing citrus greening.

Since, the major strategy for the management of HLB is eradication of the infected plants which directly impacts the grower's economy, a proper cooperation of growers will be crucial (Singerman and Rogers, 2020). Nepalese government can mitigate the loss to the growers by providing compensation to the growers who endure economic loss of certain percentage taking example from the initiative by USDA's Tree Assistance Program in the US (Olexa and Benn, 2018) and various other initiatives from these countries and implementing as much is feasible.

\section{Conclusion}

Citrus greening disease has challenged the citrus production in various areas of the world. It is imperative to rely on management strategies to mitigate the impact of HLB in citrus as there is no cure available for the disease. Several management options are practiced throughout the world in order to sustain citrus health and production under HLBendemic condition. Although some management tools require heavy economic investment and are unsuitable for small farm holder, several other options are economically feasible and environmentally sound. To rejuvenate citrus production in Nepal, it is essential to look for proper HLB management techniques and suitable HLB-vector control strategies.

\section{Authors' Contribution}

All authors contributed equally in all stages of this work. Final form of manuscript was approved by all authors.

\section{Conflict of Interest}

The authors declare that there is no conflict of interest with present publication.

\section{References}

Adhikari D, Baidya S and Koirala DK (2012) Citrus greening test on sweet orange (Junar) by scratch method at Sindhuli district. Journal of the Plant Protection Society. Plant Protection Society, Nepal. 4: 263-268.

Adhikari MK (2014) Mushrooms of Nepal (Eds) Durrieu G. Cotter and HVT Published by K.S. Adhikari, Kathmandu, GPO Box no. 21758.Nepal. Pg. 340

Albrecht U and Bowman KD (2011) Tolerance of trifoliate citrus hybrid US-897 (Citrus reticulata Blanco * Poncirus trifoliate L.Raf.) to huanglongbing. HortScience 46: 1622. DOI: $\underline{\text { 10.21273/HORTSCI.46.1.16 }}$

Albrecht U and Bowman KD (2012) Transcriptional response of susceptible and tolerant citrus to infection with Candidatus Liberibacter asiaticus. Plant Science 185: 118-130. DOI: $\underline{10.1016 / j . p l a n t s c i .2011 .09 .008}$

Alferez F, Gaire S, Albrecht U, Batuman O, Qureshi J and Zekri M (2019) IPCs for HLB Prevention in Young Trees. EDIS.

Alferez F, Vincent C and Vashisth T (2019) Update on Brassinosteroids for HLB management. Citrus Industry Magazine. June, 19.

Atta AA, Morgan KT, Kadyampakeni DM and Mahmoud KA (2021) The effect of foliar and ground-applied essential nutrients on huanglongbing-affected mature citrus trees. Plants 10: 5. DOI: $10.3390 /$ plants10050925

Baldwin E, Plotto A, Bai J, Manthey J, Zhao W, Raithore S and Irey M (2018) Effect of abscission zone formation on orange (Citrus sinensis) fruit/juice quality for trees affected by Huanglongbing (HLB). Journal of Agricultural and Food Chemistry. 66: 2877-2890. DOI: $\underline{10.1021 / \text { acs.jafc.7b05635 }}$

Bassanezi RB, Montesino LH and Stuchi ES (2009) Effects of huanglongbing on fruit quality of sweet orange cultivars in 
Brazil. European Journal of Plant Pathology. 125: 565. DOI: $10.1007 / \mathrm{s} 10658-009-9506-3$

Bhusal DR, Shrestha S and Ghimire KC (2019) Assemblage of Insects on Medicinal Plants: An Insight from ICIMOD Herbal Garden in Godavari of Lalitpur, Nepal. JIST 24: 34-41. DOI: $10.3126 /$ jist.v24i1.24626

Boina DR, Onagbola EO, Salyani M and Stelinski LL (2009) Antifeedant and sublethal effects of imidacloprid on Asian citrus psyllid, Diaphorina citri. Pest Management Science 65: 870-877. DOI: $\underline{10.1002 / \mathrm{ps} .1767}$

Bonavia E (1989) The cultivated oranges and lemons etc of India and Ceylon. WH Allen and Co London.

Bové JM (2006) Huanglongbing: a destructive, newly-emerging, century-old disease of citrus. Journal of Plant Pathology 88: 7-37. DOI: $\underline{10.2307 / 41998278}$

Bové JM (2014) Huanglongbing or yellow shoot, a disease of Gondwanan origin: Will it destroy citrus worldwide? Phytoparasitica 42: 579-583 DOI: 10.1007/s12600-014$\underline{0415-4}$

Bowman KD, McCollum G and Albrecht U (2016) Performance of 'Valencia' orange (Citrus sinensis [L.] Osbeck) on 17 rootstocks in a trial severely affected by huanglongbing. Scientia Horticulturae 201: 355-361. DOI: $\underline{10.1016 / j . s c i e n t a .2016 .01 .019}$

Budathoki K, Regmi HN, Pradhan NG, Gotame TP and Poudyal KP (2004) Citrus diversity, their characterization and evaluation in Nepal. In: Proceeding of the Forth National Workshop on Horticulture: 116: 122.

CABI (2020) Citrus Huanglongbing disease (Citrus greenging). In: Invasive Species Compendium. CABI International, Wallingford, 2020.

Catling HD (1986) Report on a visit to Nepal to survey for Diaphorina citri, the insect vector of greening disease of citrus, Rome FAO, FAO Report

Chen Q (1943) A report of a study on yellow shoot of citrus in Chaoshan. New Agric. Q. Bull, 3(142): 75.

Chien CC and Chu YI (1996) Biological control of citrus psyllid, Diaphorina citri in Taiwan. BiologicalPest Control in Systems ofIntegrated Pest Management Reprinted from Food and Fertilizer Technology Center Book Series 47: 93-104

Croxton SD and Stansly PA (2014) Metalized polyethylene mulch to repel Asian citrus psyllid, slow spread of huanglongbing and improve growth of new citrus plantings. Pest Management Science. 70: 318-323. DOI: 10.1002/ps.3566

da Graça JV (2008) Biology, history and world status of Huanglongbing in I Taller Internacional sobre Huanglongbing de los cítricos (Candidatus Liberibacter spp.) y el psílido asiático de los cítricos (Diaphorina citri) (Hermosillo), 1-7.

da Graça JV and Korsten L (2004) Citrus huanglongbing: Review, present status and future strategies. Disease offruits and vegetables 1: 229-45. DOI: 10.1007/1-4020-2606-4 4
Dala-Paula BM, Plotto A, Bai J, Manthey JA, Baldwin EA, Ferrarezi RS and Gloria MB (2019) Effect of huanglongbing or greening disease on orange juice quality, a review. Frontiers inPlant Science 9. DOI: $10.3389 /$ fpls.2018.01976

Department of Agriculture, MoAC, Government of Nepal, Food and Agriculture Organization (2011) Training Manual for Combating Citrus Decline Problem in Nepal. Retrieved from: $\quad$ https://coin.fao.org/coinstatic/cms/media/20/14364235575810/combating_citrus decline.pdf

Diwakar J, Prasai Joshi T and Jayana B (2008) Study on major pesticides and fertilizers used in Nepal. Scientific World 6: 76-80. DOI: $\underline{10.3126 / \mathrm{sw} . v 6 \mathrm{i} 6.2638}$

Doud MM, Wang Y, Hoffman MT, Latza CL, Luo W, Armstrong CM and Duan Y (2017) Solar thermotherapy reduces the titer of Candidatus Liberibacter asiaticus and enhances canopy growth by altering gene expression profiles in HLB-affected citrus plants. Horticulture Research 4: 1-9. DOI: 10.1038 /hortres.2017.54

Etxeberria EP, Gonzalez D, Dawson W and Spann T (2007) Iodine based starch test to assist in selecting leaves for HLB. In: Citrus Notes. Vol.07-08. University of Florida, USA. DOI: $\underline{10.32473 / \text { edis-hs375-2007 }}$

Gautam IP, Sah DN and Khatri B (2004) Effect of time of grafting and budding on trifoliate rootstocks for mandarin orange saplings production. Agricultural research for enhancing livelihood of Nepalese people 30: 78.

Grafton-Cardwell EE, Stelinski LL and Stansly PA (2013) Biology and Management of Asian Citrus Psyllid, Vector of the Huanglongbing Pathogens. Annual Review of Entomology 58: 413-432. DOI: 10.1146/annurev-ento$\underline{120811-153542}$

Halbert SE and Manjunath KL (2004) Asian citrus psyllids (Sternorrhyncha: Psyllidae) and greening disease of citrus: a literature review and assessment of risk in Florida. Florida Entomologist 87: 30-353. DOI: $10.2307 / 3496747$

Hall DG, Lapointe SL and Wenninger EJ (2007) Effects of a particle film on biology and behavior of Diaphorina citri (Hemiptera: Psyllidae) and its infestations in citrus. Journal of Economic Entomology 100: 847-854. DOI: 10.1603/0022-0493(2007)100[847:EOAPFO]2.0.CO;2

Hall DG, Richardson ML, Ammar ED and Halbert SE (2013) Asian citrus psyllid, Diaphorina citri, vector of citrus huanglongbing disease. Entomologia Experimentalis et Applicata 146: 207-223. DOI: $10.1111 /$ eea.12025

Hegarty JP and Stewart EB (2018) Advances in therapeutic bacterial antisense biotechnology. Applied Microbiology and Biotechnology 102: 1055-1065. DOI: $\underline{10.1007 / \mathrm{s} 00253-017-8671-0}$

Husain MA and Nath D (1927) Memoirs of the department of agriculture in India. Agriculture Research Institute, Pusa, Government of India 
Johnson EG, Wu J, Bright DB and Graham JH (2014) Association of 'Candidatus Liberibacter asiaticus' root infection, but not phloem plugging with root loss on huanglongbingaffected trees prior to appearance of foliar symptoms. Plant pathology 63: 290-298. DOI: 10.1111/ppa.12109

Juan-Blasco M, Qureshi JA, Urbaneja A and Stansly PA (2012) Predatory Mite, Amblyseius Swirskii (Acari: Phytoseiidae), for Biological Control of Asian Citrus Psyllid, Diaphorina Citri (Hemiptera: Psyllidae). Florida Entomologist 95: 543-551. DOI: 10.1653/024.095.0302

Khan AA, Qureshi JA, Afzal M and Stansly PA (2016) TwoSpotted Lady beetle Adalia bipunctata L. (Coleoptera: Coccinellidae): A Commercially Available Predator to Control Asian Citrus Psyllid Diaphorina citri (Hemiptera: Liviidae). PloS one 11(9): e0162843. DOI: $\underline{10.1371 / \text { journal.pone. } 0162843}$

Killiny N, Valim MF, Jones SE, Omar AA, Hijaz F, Gmitter FG and Grosser JW (2017) Metabolically speaking: possible reasons behind the tolerance of 'Sugar Belle' mandarin hybrid to huanglongbing. Plant physiology and Biochemistry 116: 36-47. DOI: 10.1016/j.plaphy.2017.05.001

Knorr LC, Shah SM and Gupta OP (1970) Greening disease of Citrus in Nepal. Plant Disease Reporter 54(12): 10921095.

https://swfrec.ifas.ufl.edu/hlb/database/pdf/00001962.pdf

Koltunow AM, Soltys K, Nito N, and McClure S (1995) Anther, ovule, seed, and nucellar embryo development in Citrus sinensis cv. Valencia. Canadian Journal of Botany 73: 1567-1582. DOI: $\underline{10.1139 / \mathrm{b} 95-170}$

Kunwar S, Grosser J, Gmitter FG, Castle WS and Albrecht U (2021) Field performance of 'Hamlin' orange trees grown on various rootstocks in Huanglongbing-endemic conditions. HortScience 56 244-253. DOI: 10.21273/HORTSCI15550-20

Lama TK and Shrestha PP (2004) Evaluation of rootstocks on mandarin (Citrus reticulata Blanco) with respect to vigor and citrus decline in Pokhara. Agricultural research for enhancing livelihood of Nepalese people, page: 89-91.

Li S, Wu F, Duan Y, Singerman A and Guan Z (2020) Citrus greening: management strategies and their economic impact. Hortscience 1: $1-9 . \quad$ DOI: 10.21273/HORTSCI14696-19

Li WB, Hartung JS and Levy L (2006) Quantitative real-time PCR for detection and identification of Candidatus Liberibacter sp. associated with citrus huanglongbing. Journal of Microbiological Methods 66: 104-115. DOI: 10.1016/j.mimet.2005.10.018

Manandhar R, Malla, S and Sah DN (2004). Population Dynamics of Citrus Psylla (Diaphorina citri Kuwayama) in the Western Hills of Nepal and Spread of Citrus Greening Disease. Agricultural Research for Enhancing Livelihood of Nepalese People, 30, 178.

Mann RS, Ali JG, Hermann SL, Tiwari S, Pelz-Stelinski KS, Alborn HT and Stelinski LL (2012) Induced release of a plant-defense volatile 'deceptively' attracts insect vectors to plants infected with a bacterial pathogen. PLoS Pathogens $\quad 8$ e1002610. $\underline{10.1371 / \text { journal.ppat. } 1002610}$

Mann RS, Rouseff RL, Smoot JM, Castle WS and Stelinski LL (2011) Sulfur volatiles from Allium spp. affect Asian citrus psyllid, Diaphorina citri Kuwayama (Hemiptera: Psyllidae), response to citrus volatiles. Bulletin of Entomological Research 101: 89. DOI: $\underline{10.1017 / \mathrm{S} 0007485310000222}$

McCollum G and Baldwin E (2017) Huanglongbing: devastating disease of citrus. Horticultural Reviews 44: 315-361. DOI: 10.1002/9781119281269.ch7

Michaud JP (2002) Biological control of Asian citrus psyllid, Diaphorina citri (Hemiptera: Psyllidae) in Florida: a preliminary report. Entomological News 113: 216-22

Mishra AR, Karimi D, Ehsani R and Lee WS (2012) Identification of citrus greening (HLB) using a VIS-NIR spectroscopy technique. Transactions of the ASABE 55: 711-720. DOI: $10.13031 / 2013.41369$

Molleman F, Drukker B and Blommers L (1997) A trap for monitoring pear psylla predators using dispensers with the synomone methylsalicylate. In Proceedings of the Section Experimental and Applied Entomology of the Netherlands Entomological Society.. 8: 1770182

Morgan KT, Rouse RE and Ebel RC (2016) Foliar applications of essential nutrients on growth and yield of 'Valencia' sweet orange infected with Huanglongbing. HortScience 51: 1482-1493. DOI; $10.21273 /$ HORTSCI11026-16

Nehela Y and Killiny N (2020) Revisiting the complex pathosystem of huanglongbing: Deciphering the role of citrus metabolites in symptom development. Metabolites 10: 409. DOI: 10.3390/metabo10100409

Olexa MT and Benn JT (2018) Feeling the sqeez: citrus greening policy in the westers Hemisphere. Drake J. Agric. L. 23: 173.

Onagbola E, Rouseff R, Smoot J and Stelinski L (2011) Guava leaf volatiles and dimethyl disulphide inhibit response of Diaphorina citri Kuwayama to host plant volatiles. Journal of Applied Entomology 135: 404-414. DOI: 10.1111/j.1439-0418.2010.01565.x

Paudyal KP (2015) Techological advances in Huanglongbing (HLB) or citrus greening disease management. Journal of Nepal Agricultural Research Council 1: 41-50. DOI: $\underline{10.3126 / \text { jnarc.v1i0.15735 }}$

Phuyal D, Nogueira TAR, Jani AD, Kadyampakeni DM, Morgan KT and Ferrarezi RS (2020) 'Ray Ruby' grapefruit affected by Huanglongbing i. planting density and soil nutrient management. HortScience 55: 1411-1419. DOI: 10.21273/hortsci15111-20

Pitino M, Sturgeon K, Dorado C, Cano LM, Manthey JA, Shatters Jr RG and Rossi L (2020) Quercus leaf extracts display curative effects against Candidatus Liberibacter asiaticus that restore leaf physiological parameters in HLB-affected citrus trees. Plant Physiology and Biochemistry 148: 7079. DOI: $\underline{10.1016 / j . p l a p h y .2020 .01 .013}$ 
Pokhrel S, Meyering B, Bowman KD and Albrecht U (2021) Horticultural attributes and root architectures of fieldgrown 'Valencia' trees grated on different rootstocks propagated by seed, cuttings, and tissue culture. HortScience, $\quad$ 56: 163-172. DOI: $\underline{\text { 10.21273/HORTSCI15507-20 }}$

Puttamuk T, Zhang S, Duan Y, Jantasorn A and Thaveechai N (2014) Effect of chemical treatments on 'Candidatus Liberibacter asiaticus' infected pomelo (Citrus maxima). Crop Protection 65: 114-121. DOI: 10.1016/j.cropro.2014.07.018

Qureshi JA and Stansly PA (2007) Integrated approaches for managing the Asian citrus psyllid Diaphorina citri (Homoptera: Psyllidae) in Florida. In proceedings of the Florida state Horticultural Society 120: 110-115.

Qureshi JA and Stansly PA (2009) Exclusion techniques reveal significant biotic mortality suffered by Asian citrus psyllid Diaphorina citri (Hemiptera: Psyllidae) populations in Florida citrus. Biological Control 50: 129-136. DOI: $\underline{10.1016 / \text { j.biocontrol.2009.04.001 }}$

Ramadugu C, Keremane ML, Halbert SE, Duan YP, Roose ML, Stover E and Lee RF (2016) Long-term field evaluation reveals Huanglongbing resistance in Citrus relatives. Plant Diseases 100: 1858-1869. DOI: 10.1094/PDIS-03-160271-RE

Regmi C (1982) Mycoplasma-like disease of citrus in Nepal and USSR (spread, effect, etiology, varietal resistance, possible vectors). Ph.D. dissertation. Moscow Agricultural Academy, Moscow 144.

Regmi C and Yadav BP (2007) Present status of Huanglongbing in western district of Nepal. In Proc 4th Hort. Seminar, Jan (18-19).

Regmi C, Devkota RP, Paudyal KP, Shrestha S, Ayres AJ, Murcia N, Bove JM and Duran-Vila N (2010) Shifting from seedling mandarin trees to grafted trees and controlling huanglongbing and viroids: a biotechnological revolution in Nepal. Paper presented at the International Organization of Citrus Virologists Conference Proceedings 1957-20100. DOI: 10.5070/C54F74W8P0

Rizvi SAH, Ling SQ, Tian FJ, Xie F and Zeng XNA (2018) Toxicity and enzyme inhibition activities of the essential oil and dominant constituents derived from Artemisia absinthium L. against adult Asian citrus psyllid Diaphorina citri Kuwayama (Hemiptera: Psyllidae). Industrial Crops and Products 121: 468-475. DOI: $\underline{10.1016 / j . i n d c r o p .2018 .05 .031}$

Roastcher CN (1996) The economics of living with citrus diseases: Hunaglongbing (greening) in Thailand. In: proceedings of the Thirteenth IOCV conference - procaryotes and blight (JV da Graca, P Moreno, RK Yokimi eds). 16-23 Nov,1996, Fujian, China, 279-285

Rouseff RL, Onagbola EO, Smoot JM and Stelinski LL (2008) Sulfur volatiles in guava (Psidium guajava L.) leaves: possible defense mechanism. J Agric Food Chem 56: 8905-8910. DOI: $10.1021 / \mathrm{jf801735v}$
Singerman A (2019) The real cost of HLB in Florida. Citru Industry 2019:10-13. DOI: $10.32473 /$ edis-fe1050-2018

Singerman A and Rogers ME (2020) The economic challenges of dealing with citrus greening: The case of Florida. Jorunal ofIntegrated Pest Management 11: 3. DOI: $\underline{10.1093 / \mathrm{jipm} / \mathrm{pmz} 037}$

Singh BP (1977) Physiopathological studies on citrus decline. In: Proceeding of International Symposium on Citriculture. Horticulture Society of India.

Taba Sk Nasu, Takaesu K, Ooshiro A and Moromizato Z (2006) Detection of citrus huanglongbing using an iodo-starch reaction. The Science Bulletin of the Faculty of Agriculture, University of the Ryukyus 53: 19-24

Taylor RA, Ryan SJ, Lippi CA, Hall DG, Narouei-Khandan HA, Rohr JR and Johnson LR (2019) Predicting the fundamental thermal niche of crop pests and diseases in a changing world: a case study on citrus greening. Journal of Applied Entomology. 56: 2057-2068. DOI: $\underline{10.1111 / 1365-2664.13455}$

Thrower LB (1986) Report on visit to Nepal. FAO report PL:T51

Tiwari S, Mann RS, Rogers ME and Stelinski LL (2011). Insecticide resistance in field populations of Asian citrus psyllid in Florida. Pest anagement Science 67: 1258-1268. DOI: $10.1002 / \mathrm{ps} .2181$

Tsai JH and Liu YH (2000) Biology of Diaphorina citri (Homoptera: Psyllidae) on four host plants. Journal of Economic Entomology. 93: 1721-1725. DOI: $\underline{10.1603 / 0022-0493-93.6 .1721}$

Uthman QO, Kadyampakeni DM, Nkedi-Kizza P, Barlas NT, Atta AA and Morgan KT (2020) Comparative response of huanglongbing-affected sweet orange trees to nitrogen and zinc fertilization under microsprinkler irrigation. Agriculture (Switzerland) 10: $1-15$. DOI: $\underline{10.3390 / \text { agriculture } 10100489}$

Van der Merwe AJ and Andersen FG (1937) Chromium and Manganese toxicity. It is important in Transvaal citrus greening ? Farming South Africa 12: 439-440

Vashisth T (2016) Managing the health and productivity of HLBaffected groves. EDIS. DOI: 10.32473/edis-pp328-2016

Vashisth T and Kadyampakeni D (2020) Diagnosis and management of nutrient constraints in citrus. In Fruit crops. 723-737. DOI: 10.1016/B978-0-12-8187326.00049-6

Wang Q, Bao W, Zhang Q, Fu X, Yang Y and Lu Y (2019). Host plant use of a polyphagous mirid, Apolygus lucorum: Molecular evidence from migratory individuals. Ecology and Evolution9: 11518-11528. DOI: $10.1002 / \mathrm{ece} 3.5660$

Weinert MÁ, Jacobson SC, Grimshaw JF, Bellis GA, Stephens PM, Gunua TG, Kame MF and. Davis RI (2004) Detection of huanglongbing (citrus greening disease) in Timor-Leste (East Timor) and in Papua New Guinea. Australasian Plant Pathology 33 : 135-136. DOI: 10.1071/ap03089

Wenninger EJ, Stelinski LL and Hall DG (2009) Roles of olfactory cues, visual cues, and mating status in orientation of 
Diaphorina citri Kuwayama (Hemiptera: Psyllidae) to four different host plants. Environmental Entomology 38: 225-234. DOI: $10.1603 / 022.038 .0128$

Wesolowski D, Alonso D and Altman S (2013) combined effect of a peptide morpholino oligonucleotide conjugate and a cell-penetrating peptide as an antibiotics. Proceedings of the National Academy of Sciences of the United States of America 110: 8686-8689. DOI: 10.1073/pnas.1306911110

Yan H, Zeng J and Zhong G (2015) The push-pull strategy for citrus psyllid control. Pest Management Science 71 : 893896. DOI: $10.1002 / \mathrm{ps} .3915$

Yijing C, Junming Y, Changbao X and Anwei F (2005) The taxis of Diaphorina citri to the volatile oils extracted from nonhost plants. Journal of South China Agricultural University. 26: 41-44.

Zhang M, Powell CA, Zhou L, He Z, Stover E and Duan Y (2011) Chemical compounds effective against the citrus huanglongbing bacterium 'Candidatus Liberibacter asiaticus' in planta. Phytopathology 101: 1097-1103. DOI: $\underline{\text { 10.1094/PHYTO-09-10-0262 }}$

Zhao JP, Wang HT, Zeng XN and Xue PP (2013) Differences in selection behaviors and chemical cues of adult Asian citrus psyllids, Diaphorina citri, on healthy and huanglongbinginfected young shoots of citrus plants. Journal of Agricultural Science 5: 83-91. DOI: 10.5539/jas.v5n9p83

Zhao XY (1981) Citrus yellow shoot disease (Huangloingbing)- a review. In Proceeding of the International Society of Citrus culture.1 : 466-469

Zheng Y, Kumar N, Gonzalez P and Etxeberria E (2018) Strigolactones restore vegetative and reproductive developments in Huanglongbing (HLB) affected, greenhouse-grown citrus trees by modulating carbohydrate distribution. Scientia. Horticulturae. 237: 89-95. DOI: $10.1016 /$ j.scienta.2018.04.017 